\title{
Phytochemical Screening and Antimicrobial Activity of the Pulp Extract and Fractions of Ziziphus mauritiana
}

Mbahi MA ${ }^{1 *}$, Mbahi AM ${ }^{2}$, Umar IA $^{1}$, Ameh DA ${ }^{1}$, Joseph $\mathrm{I}^{3}$ and Amos $\mathrm{PI}^{3}$

${ }^{1}$ Department of Biochemistry, Ahmadu Bello University, Nigeria

${ }^{2}$ Department of Biological sciences, Federal university kashere, gombe state, Nigeria

${ }^{3}$ Department of Chemistry, Nanomaterials Research Group, School of Pure and Applied Sciences, Modibbo Adama University of Technology, Nigeria

\begin{abstract}
The methanol pulp extract of Ziziphus mauritiana was investigated for the presence of bioactive substances and antibacterial activity against Escherichia coli, Staphyloccus aureus, Salmonela typhi and Bacillus subtilis using the agar diffusion method. The result of phytochemical test indicated that tannins, flavonoids, saponin, cyanogenic glycosides, and terpenoids were present in pulp. The result of antibacterial studies indicates that the crude extract as well as fractions possesses significant activity against the tested organisms. The extract and its fraction also possess good inhibitory activity; hence can be used as antibacterial agent
\end{abstract}

Keywords: Ziziphus mauritiana; Escherichia coli; Bacillus subtilis; Staphylococcus aureus; Salmonella typhi

\section{Introduction}

Bioactive components are naturally found everywhere in most dietary higher plants available to humans and livestock. The natural products such as plant extracts provide unlimited opportunities for new drug discoveries, mostly because of plethora of varieties of phytochemicals $[1,2]$. Literally Phytochemicals (from the Greek word phyto, meaning plant) are biologically active, naturally occurring chemical compounds found in plants, which provide health benefits for humans and livestock further than those attributed to macronutrients and micronutrients [3]. Plant extracts have therapeutic effect with or without chemical modification for various infectious diseases cause by bacterial activities and other disease-causing organisms [4,5]. Plants used for the treatment of diseases is as old as mankind, medicinal plants are an important source of potentially useful structures for the development of new chemotherapeutic agents. The first step towards achieving this goal is the in vitro [6] antibacterial activity studies [5] which reported that the methanol leaf extracts of Ziziphus mauritiana showed significant activity against some certain bacteria and shows potentials to have powerful antibacterial effect. Also reports [7-9] on the antiviral, antibacterial, antifungal, anthelmintic, antimolluscal and anti-inflammatory properties of plants, some of these observations have helped in identifying the active phytochemicals responsible for such therapeutic activities and in developing synthetic drugs for the treatment and management of a number of ailments in human beings. Ziziphus mauritiana belongs to the family Rhamnaceae. It is widely grown in mild-temperate region and is adapted to warm climates. Ziziphus mauritiana can grow either as shrublets, shrubs or trees with thorny branches and are used as a hedge to form defensive fences for animals. The plant is known with many local names including jujube, Chinese date, Indian plump [10]. It is called "Magarya" in Hausa or "Huhue" in bura among the northern people of Nigeria. Several reports on the traditional uses of Ziziphus mauritiana have been reported [11] In this work Phytochemical Screening and Antimicrobial Activity of the pulp extract and fractions of Ziziphus Mauritiana was investigated against Escherichia coli, Staphyloccus aureus, Salmonela typhi and Bacillus subtilis using the agar diffusion method.

\section{Materials and Method}

\section{Test organisms}

The test microorganisms which include Escherichia coli, Bacillus subtilis, Staphylococcus aureus, and Salmonellatyphi were obtained from the department of Microbiology, Ahmadu Bello University Teaching Hospital Shika Zaria, Kaduna State and were maintained in nutrient agar slant at $40^{\circ} \mathrm{C}$ before used as described earlier [12]. The plate of the test organisms was gotten from isolate culture of agar slants. The isolates were sub-cultured on selective and differential media and reidentified using colony morphology, gram reaction mortality test and haemolytic activity and biochemical test (catalyst, bile solubility, litmus milk, citrate, oxidase and fermentation of sugars-mannitol, lactose and sorbitol [13]), with wire loop colonies of culture of bacterial culture were picked and suspended in $5 \mathrm{ml}$ nutrient broth in $10 \mathrm{ml}$ bottles and were incubated at $37^{\circ} \mathrm{C}$ for $24 \mathrm{hrs}$.

\section{Collection of plant material}

Pulp of Ziziphus mauritiana were collected from Hyera village of Hawul local Government Borno State, Nigeria, identified and authenticated at the herbarium of department of biological Sciences, Ahmadu Bello University with the voucher number 295.

\section{Preparation of plant extracts}

The dry pulp of $Z$. mauritiana was pulverized using pestle and mortar and sieved. About $200 \mathrm{~g}$ of the coarse powdered pulp was extracted with

*Corresponding author: Mbahi MA, Department of Biochemistry, Ahmadu Bello University, Nigeria, Tel: +234-706-427-621-7; E-mail: Asugum@yahoo.com

Received: February 28, 2018; Accepted: April 04, 2018; Published April 16, 2018

Citation: Mbahi MA, Mbahi AM, Umar IA, Ameh DA, Joseph I, et al. (2018) Phytochemical Screening and Antimicrobial Activity of the Pulp Extract and Fractions of Ziziphus mauritiana. Biochem Anal Biochem 7: 352. doi: 10.4172/21611009.1000352

Copyright: ( $) 2018$ Mbahi MA, et al. This is an open-access article distributed unde the terms of the Creative Commons Attribution License, which permits unrestricted use, distribution, and reproduction in any medium, provided the original author and source are credited. 
$1000 \mathrm{ml}$ of $90 \%$ methanol by cooled maceration. Methanol was evaporated in water bath at less than $400^{\circ} \mathrm{C}$. Distilled water was used to reconstitute the solid extract to obtain a desired concentration for the studies.

Preparation of stock solution of extract: The stock solution was prepared by dissolving $1.0 \mathrm{~g}$ of the extract in $10 \mathrm{ml}$ of distilled water to get a concentration of $100 \mathrm{mg} / \mathrm{ml}$ the stock solution was reconstituted to a graded concentration of $50 \mathrm{mg} / \mathrm{ml}, 25 \mathrm{mg} / \mathrm{ml}$ and $12.5 \mathrm{mg} / \mathrm{ml}$ by two fold dilution this was stored at $4^{\circ} \mathrm{C}$.

\section{Preliminary phytochemical screening and quantitative test}

Preliminary phytochemical screening and quantitative test for the presence of phenols, tannins, flavonoids, alkaloids, terpenoids, anthraquinones, steroid and saponins was carried out using standard test protocols [10]. These phytochemicals were identified by characteristics colour change using standard procedures [14].

Test for alkaloids: To the $0.2 \mathrm{~g}$ of the extract, $2 \mathrm{ml}$ of picric acid was added. Orange colouration indicates the presence of alkaloids.

Test for saponins: The plant extract $(0.5 \mathrm{~g})$ was shaken with water in a test tube and was heated to boil. Frothing was observed which was taken as a preliminary evidence for the presence of saponin.

Test for tannins: Extract $(0.5 \mathrm{~g})$ was added to $10 \mathrm{ml}$ of water in a test tube and filtered. A few drops of $0.1 \%$ ferric chloride was added and observed for brownish green or blue-black coloration.

Test for steroids: Acetic anhydride $(2 \mathrm{ml})$ was added to $0.5 \mathrm{~g}$ of methanol extract of each sample with $2 \mathrm{ml}$ sulphuric acid. A colour change from violet to blue or green in some samples was an indication of the presence of steroids.

Test for flavonoids: Ethylacetate $(10 \mathrm{ml})$ was added to small portion of the powdered plant material and it was held over steam bathe for 3 minutes. The mixture was filtered and $1 \mathrm{ml}$ of dilute ammonia solution was added to $4 \mathrm{ml}$ of the filterate and then shaken. A yellow colouration indicates the presence of flavonoids [15].

Test for anthraquinones: Extract $(0.5 \mathrm{~g})$ was taken in a dry test tube and $5 \mathrm{ml}$ of chloroform was added and shaken for $5 \mathrm{~min}$. The extract was filtered and the filtrate shaken with equal volume of $10 \%$ of ammonia solution. A pink violet or red colour in the ammonical layer indicates the presence of anthraquinones.

Test for Phenols: The powdered ( $0.5 \mathrm{~g}$ ) plant material was boiled with $10 \mathrm{ml}$ of sulphuric acid and filtered while hot, $5 \mathrm{ml}$ of chloroform was added and shaken. The chloroform layer was then pipetted into another test tube and $1 \mathrm{ml}$ of dilute ammonia was added to it. The resulting solution was observed for colour changes to green-blue or violent.

Test for cynogenic glycosides: To $0.5 \mathrm{~g}$ of the extract $10 \mathrm{ml}$ of $50 \%$ $\mathrm{H}_{2} \mathrm{SO}_{4}$ was added and the mixture heated in boiling water for about 15 min. Fehling's solution $(10 \mathrm{ml})$ was then added and the mixture boiled. A brick-red precipitate was confirmatory for the presence of glycosides.

Test for terpenoids: A little portion of the sample was dissolve. To it $1 \mathrm{ml}$ of acetic acid anhydride was added followed by addition of conc. $\mathrm{H}_{2} \mathrm{SO}_{4}$. A change in colour from pink to violent showed the presence of terpenoids.

Flavonoids: Ten (10) gram of powdered sample was extracted repeatedly with $100 \mathrm{ml}$ of $80 \%$ aqueous methanol at room temperature. The whole solution was filtered through Whatman filter paper. The filtrate was transferred into a crucible and evaporated to dryness over a water bath and weighed.
Tannins: The powdered sample $(0.1 \mathrm{~g})$ was placed into $100 \mathrm{ML}$ conical flask and $50 \mathrm{ML}$ of distilled water was added. The flask was gently heated to boiling for 1 hour, filtered hot and filtrate collected in $50 \mathrm{~cm}^{3}$ volumetric flasks. The residue was washed several times and the combined solution made to the volume with distilled water. To 0 , $1,2,3,4$ and $5 \mathrm{ml}$ of the standard tannic acid and $10 \mathrm{~cm}^{3}$ of the sample solution in a $50 \mathrm{~cm}^{3}$ volumetric flask, $2.5 \mathrm{~cm}^{3}$ Folin-Denis reagent and $10 \mathrm{~cm}^{3}$ of $\mathrm{Na}_{2} \mathrm{CO}_{3}$ solution was added and made up to volume with distilled water. The flasks were allowed to stand for 20 minutes after which optical density was measured at $750 \mathrm{~nm}$. The calibration curve was plotted from which the concentration of tannic acid (13X) in the sample was extrapolated and tannins content in the sample was calculated [16].

Saponins: Five $(5 \mathrm{~g})$ gram of the powdered sample was placed in a $100 \mathrm{~cm}^{3}$ flask. $60 \mathrm{~cm}^{3}$ of $50 \%$ aqueous methanol was added to the content and boiled under reflux for 30 minutes. The resulting solution was filtered while hot using filter paper into a $100 \mathrm{~cm}^{3}$ flask. Two $(2 \mathrm{~g})$ gram charcoal were subsequently added to the filtrate, further boiled and filtered while hot. The extract was allowed to cool and equal volume of acetone was added (to complete precipitation of saponins). The precipitate was separated by decantation and then dissolved in $95 \%$ ethanol by boiling, filtered while hot and allowed to cool to room temperature. The filter paper containing the residue was dried in a dessicator and weighed.

$\%$ of Saponins=Weight of saponin residue/Weight of sample x 100

or

\% Saponin=W2 $-\mathrm{W} 1 / \mathrm{W} 3 \times 100$

Where $\mathrm{W} 1=$ Weight of filter paper

W2=Weight of filter paper + Extract

W3=Initial weight of sample

Glycosides: One (1) gram of the extract was extracted with $10 \mathrm{ml}$ of $70 \%$ alcohol and the mixture was filtered. $8 \mathrm{ml}$ of the filtrate was transferred to $100 \mathrm{ml}$ volumetric flask and the volume was completed to the mark with distilled water. $8 \mathrm{ml}$ of the mixture was added to 8 $\mathrm{ml}$ of $12.5 \%$ lead acetate (to precipitate resins, tannin and pigments). The mixture was shaken very well and was completed to the volume with distilled water and filtered. $50 \mathrm{ml}$ of the filtrate was pipette into another $100 \mathrm{ml}$ volumetric flask and $8 \mathrm{ml}$ of $4.7 \%$ disodium hydrogen phosphate $\left(\mathrm{Na}_{2} \mathrm{HPo}_{4}\right)$ solution (to precipitate excess lead) was added, the mixture was made up to the volume with distilled water and mixed. The mixture was filtered twice through a filter paper. Baljet's reagent $(10$ $\mathrm{ml}$ ) was added to $10 \mathrm{ml}$ of the purified filtrate. A blank sample of $10 \mathrm{ml}$ of distilled water was added to Baljet's reagent. The two solutions were allowed to stand for one hour (time necessary for colour development). A blank of $20 \mathrm{ml}$ of distilled water was used. The intensity of colour was read at $495 \mathrm{~nm}$ with a spectrophotometer. The percentage of total glycosides was calculated by referring to the given standard curve.

The percentage of glycosides $=\mathrm{A} \times 40 \times 100 / 170 \times 100 \times 0.04$

$=\mathrm{A} \times 100 / 17$

Where $\mathrm{A}=$ Absorbance of the sample at $495 \mathrm{~nm}$.

\section{Fractionation}

Solvent-solvent fractionation was done by suspending the crude extract in warm water at $40^{\circ} \mathrm{C}$ to dissolve. The solution was then partitioned successively using the following solvent $n$-hexane, 
ethylacetate, and n-butanol. Shaking the separating funnel mixture separate into two layers and it was collected separately the fractions collected were evaporated to dryness at $40^{\circ} \mathrm{C}$ and kept in a tight container for further analysis.

\section{Preparation of nutrient agar}

Nutrient agar was prepared for this study by weighing $28 \mathrm{~g}$ of the powdered agar and dissolved in $1000 \mathrm{ml}$ of distilled water in a conical flask. It was then autoclaved at $121^{\circ} \mathrm{C}$ for 15 minutes. After sterilization, it was allowed to cool at room temperature and the content was poured aseptically into a sterile petri-dish and allowed to solidify.

\section{Antimicrobial activity study of the extract.}

Agar well diffusion and broth dilution technique was used to test for antimicrobial activity in accordance with the method described by Irobi et al. [17]. The antimicrobial activity of the plant was tested on E.coli, S. aureus, Salmonela typhi and Bacillus subtilis. Isolates were first grown in a nutrient broth for $18 \mathrm{~h}$ before use and standardized to $0.5 \mathrm{McFarland}$ standards $(106 \mathrm{cfu} / \mathrm{ml})$. Two hundred micro liters of the standardized cell suspensions was spread on a Mueller-Hinton agar (Oxoid). Wells were then bored into the agar using a sterile 6 mm diameter cork borer. Approximately $100 \mu^{\mathrm{l}}$ of the crude extract at $10 \mathrm{mg} / \mathrm{ml}$ was then introduced into the wells, and was allowed to stand at room temperature for about $2 \mathrm{~h}$ and then incubated at $37^{\circ} \mathrm{C}$. Negative Controls was set up in parallel using the solvents that was used to reconstitute the extract and the solvent used for extraction, ciprofloxacin was used as the positive control. The plates were observed for zones of inhibition after $24 \mathrm{~h} \mathrm{[18].}$

\section{Statistical analysis}

Data obtained from the experiment were statistically analyzed and the results of the experiment expressed as means \pm SD.

\section{Result and Discussion}

Result of phytochemical screening (Table 1) revealed the presence of tannins, flavonoids, saponins, terpenoids, and cyanogenic glycosides in the pulp. Alkaloids, steroids and anthraquinones were not detected. The anti-bacterial studies results (Tables 2-11) suggested that methanol extracts of the pulp showed varying degree of anti-bacterial activity. The pulp extract showed potent activity against all the organisms tested at $100 \mathrm{mg} / \mathrm{ml}$ and $50 \mathrm{mg} / \mathrm{ml}$ and showed no zone of inhibition at $25 \mathrm{mg} /$ $\mathrm{ml}$ and $12.5 \mathrm{mg} / \mathrm{ml}$, except for salmonella typhi with a zone of inhibition of $12.00 \pm 0.00 \mathrm{~mm}$ at $25 \mathrm{mg} / \mathrm{ml}$. The inhibitory activity of ciprofloxacin; the standard commercial anti-bacterial drug which serve as a positive control against these bacterial pathogens were more efficacious than for the pulp. The antimicrobial activity observed by both crude and fractionated extracts may be attributed to the presence of secondary metabolites like terpenoids, glycosides as proposed by previous reports $[19,20]$.

\begin{tabular}{|c|c|c|}
\hline Number & Fractions & Eluting Solvent \\
\hline A & $1-14$ & Hexane absolute \\
\hline B & $15-30$ & $08: 02$ \\
\hline C & $31-46$ & $06: 04$ \\
\hline D & $47-64$ & $04: 06$ \\
\hline E & $65-81$ & $02: 08$ \\
\hline F & $82-100$ & Ethylacetate absolute \\
\hline
\end{tabular}

Table 1: Fractions obtained from the column chromatography of ethylacetate fraction.
Since the methanol crude extract of the pulp exhibited pronounced antimicrobial activity against the organisms tested, it was subjected to partitioning using water, n-hexane, ethylacetate, and n-butanol. Ethyl acetate fraction of the pulp methanol extract possessed inhibitory activity against the entire tested organism at 25,50 and $100 \mathrm{mg} / \mathrm{ml}$, with a zone of inhibition ranging from $13.00-16.50 \mathrm{~mm}$. Two possibilities that may account for the higher antibacterial activity of this solvent is the nature of biological active components (flavonoids, terpenoids, tannins, etc.), which may be enhanced in the presence of ethylacetate and the stronger extraction capacity of the solvent that may have yielded a greater number of active constituents responsible for antibacterial activity $[21,22]$. n-Hexane showed inhibitory activity at 25, 50 and 100 $\mathrm{mg} / \mathrm{ml}$ against Bacillus subtilis only. $\mathrm{n}$-Butanol inhibited the growth of Bacillus subtilis and Staphylococcus aureus at doses of 25,50 and $100 \mathrm{mg} /$ $\mathrm{ml}$ and at 50 and $100 \mathrm{mg} / \mathrm{ml}$ respectively. The aqueous fraction had no effect on the tested organisms. It was also observed that the antimicrobial activity of the pulp extract improved with increase in concentration of the extract which also suggest that apart from the presence of the aforementioned biological active components responsible for the said antimicrobial activities, increase in concentration of the extract is also a contributor. The zones of inhibition of the test organism and their susceptibility to the different solvents fractions of the extracts, varied from one organism to another. According to Prescott, et al. [23], effect of an agent varies with target species. The position of the zone edge (diameter of zone of inhibition) is determined by the initial population density of the organism, their growth rate and the rate of diffusion of the antimicrobial agent. These explain the differences in the zones of inhibition observed in the experiments. The inhibitory effects may as well be attributed to the presence of bioactive metabolites. Several reports have shown that bioactive compounds isolated from plant extract have growth inhibitory effect on pathogenic strains [23]. Plants are rich in wide variety of secondary metabolites such as tannins, terpenoids, alkaloids and flavonoids which have been found to have antimicrobial properties in vitro. In addition, combination of some of these chemical substances found in herbal preparations synergistically forms a natural mixture with antimicrobial spectrum. Tannins a polymeric phenolic substance has been associated with several physiological activities such as stimulation of phagocytic cells, host mediated tumor activity and a wide range of anti-infective actions. Their mode of antimicrobial action may be related to their ability to inactivate microbial enzymes and transport proteins.

Some of these metabolites particularly some flavonoids that were detected were reported to be responsible for antimicrobial activity associated with some ethno-medicinal plants [24]. In addition, some alkaloids and tannins are well documented for antimicrobial activity $[25,26]$. The persistent increase in multidrug resistant strains compels the search for more potent new antibiotics. Thus, there is a need for

\begin{tabular}{|c|c|}
\hline Phytochemical & Fruits \\
\hline Phenolics & - \\
\hline Tannins & + \\
\hline Flavonoids & - \\
\hline Alkaloids & + \\
\hline Saponin & - \\
\hline Steroids & + \\
\hline Cyanogenic glycoside & - \\
\hline Anthraquinones & + \\
\hline Terpenoids & \\
\hline + Present, - Absent & \\
\hline
\end{tabular}

Table 2: Result of preliminary qualitative phytochemical screening 
Citation: Mbahi MA, Mbahi AM, Umar IA, Ameh DA, Joseph I, et al. (2018) Phytochemical Screening and Antimicrobial Activity of the Pulp Extract and Fractions of Ziziphus mauritiana. Biochem Anal Biochem 7: 352. doi: 10.4172/2161-1009.1000352

Page 4 of 6

\begin{tabular}{|c|c|c|c|c|}
\hline Organism & \multicolumn{3}{c|}{ Concentration of extract(mg/ml)/standard drug $(\boldsymbol{\mu g})$} \\
\hline & 100 & 50 & 25 & 12.5 \\
\hline Bacillus subtilis & $25.00 \pm 4.24^{\mathrm{b}}$ & $20.00 \pm 0.00^{\mathrm{a}}$ & - & - \\
\hline Staphylococcus aureus & $17.00 \pm 0.00^{\mathrm{b}}$ & $11.50 \pm 2.12^{\mathrm{a}}$ & - & - \\
\hline Escherichia coli & $27.00 \pm 1.41^{\mathrm{b}}$ & $21.00 \pm 1.41^{\mathrm{a}}$ & - & - \\
\hline Salmonella typhi & $19.00 \pm 1.41^{\mathrm{c}}$ & $14.50 \pm 0.70^{\mathrm{a}}$ & $12.00 \pm 0.00^{\mathrm{a}}$ & - \\
\hline $\begin{array}{l}\text { Values are in mean } \pm \text { SD of double determinations. Values with different superscripts across the column are significantly different (p<0.05). Cipro: Ciprofloxacin, -: No } \\
\text { zone of Inhibition. }\end{array}$
\end{tabular}

Table 3: Zone of inhibition ( $\mathrm{mm}$ ) of methanol crude extract of pulp.

\begin{tabular}{|c|c|c|c|c|}
\hline Organism & \multicolumn{3}{c|}{ Concentration of extract $(\mathbf{m g} / \mathbf{m l}) / \mathbf{s t a n d a r d ~ d r u g ~}(\boldsymbol{\mu g})$} \\
\hline & $\mathbf{1 0 0}$ & $\mathbf{5 0}$ & $\mathbf{2 5}$ & - \\
\hline Bacillus subtilis & - & - & - & - \\
\hline Staphylococcus aureus & - & - & - \\
\hline Escherichia coli & - & - & - \\
\hline Salmonella typhi & - & - & - \\
\hline Values are in mean \pm SD of double determinations. Values with different superscripts across the column are significantly different (p<0.05). Cipro: Ciprofloxacin, -: No
\end{tabular}

Table 4: Zone of inhibition $(\mathrm{mm})$ of aqueous fraction of the pulp.

\begin{tabular}{|c|c|c|c|c|}
\hline Organism & \multicolumn{3}{|c|}{ Concentration of extract(mg/ml)/standard drug $(\boldsymbol{\mu g})$} \\
\hline & 100 & 50 & 25 & 12.5 \\
\hline Bacillus subtilis & $12.00 \pm 1.41^{\mathrm{b}}$ & $10.00 \pm 0.70^{\mathrm{a}}$ & $10.00 \pm 0.70^{\mathrm{a}}$ & - \\
\hline Staphylococcus aureus & $13.00 \pm 0.00^{\mathrm{b}}$ & $10.00 \pm 0.00^{\mathrm{a}}$ & - & - \\
\hline Escherichia coli & - & - & - & - \\
\hline Salmonella typhi & - & - & - & - \\
\hline Values are in mean \pm SD of double determinations. Values with different superscripts across the column are significantly different (p<0.05). Cipro: Ciprofloxacin, -: No
\end{tabular}

Table 5: Zone of Inhibition ( $\mathrm{mm}$ ) of n-butanol Fraction of the pulp.

\begin{tabular}{|c|c|c|c|c|c|}
\hline \multirow[t]{2}{*}{ Organism } & \multicolumn{5}{|c|}{ Concentration of extract $(\mathrm{mg} / \mathrm{ml}) /$ standard drug $(\mu \mathrm{g})$} \\
\hline & 100 & 50 & 25 & 12.5 & Cipro (10) \\
\hline Bacillus subtilis & $14.00 \pm 1.41^{b}$ & $10.00 \pm 0.00^{a}$ & - & - & $38.00 \pm 0.00^{\mathrm{a}}$ \\
\hline Staphylococcus aureus & $16.50 \pm 0.70^{\mathrm{b}}$ & $13.00 \pm 0.00^{b}$ & $10.00 \pm 0.00^{\mathrm{a}}$ & - & $38.50 \pm 0.50^{b}$ \\
\hline Escherichia coli & $13.00 \pm 1.41^{b}$ & $10.00 \pm 0.00^{\mathrm{a}}$ & - & - & $36.50 . \pm 0.50^{\mathrm{C}}$ \\
\hline Salmonella typhi & $13.50 \pm 0.70^{\mathrm{b}}$ & $10.50 \pm 0.70^{\mathrm{a}}$ & $10.00 \pm 0.00^{\mathrm{a}}$ & - & $40.00 \pm 0.00^{c}$ \\
\hline
\end{tabular}
zone of Inhibition.

Table 6: Zone of Inhibition ( $\mathrm{mm}$ ) of Ethylacetate Fraction of the pulp

\begin{tabular}{|c|c|c|c|c|c|}
\hline \multirow[t]{2}{*}{ Organism } & \multicolumn{5}{|c|}{ Concentration of extract $(\mathrm{mg} / \mathrm{ml}) /$ standard drug $(\mu \mathrm{g})$} \\
\hline & 100 & 50 & 25 & 12.5 & Cipro (10) \\
\hline Bacillus subtilis & $14.00 \pm 1.41^{b}$ & $12.50 \pm 0.70^{\mathrm{ab}}$ & $11.50 \pm 0.70^{\mathrm{a}}$ & - & $38.00 \pm 0.00^{c}$ \\
\hline Staphylococcus aureus & - & - & - & - & $38.50 \pm 0.50^{\mathrm{a}}$ \\
\hline Escherichia coli & - & - & - & - & $36.50 . \pm 0.50^{a}$ \\
\hline Salmonella typhi & - & - & - & - & $40.00 \pm 0.00^{a}$ \\
\hline
\end{tabular}

Table 7: Zone of inhibition ( $\mathrm{mm}$ ) of $\mathrm{n}$-hexane Fraction of the pulp.

\begin{tabular}{|c|c|c|c|c|}
\hline \multirow[t]{2}{*}{ Conc/Std $(\mu \mathrm{g})$} & \multicolumn{4}{|c|}{ Zone of Inhibition (mm) } \\
\hline & A & B & C & D \\
\hline 50 & - & - & $29.50 \pm 0.70^{b}$ & - \\
\hline 25 & - & - & $26.00 \pm 1.41^{a}$ & - \\
\hline 12.5 & - & - & $25.00 \pm 0.00^{\mathrm{a}}$ & - \\
\hline 6.5 & - & - & $24.00 \pm 1.41^{\mathrm{a}}$ & - \\
\hline Cipro 10 & $38.00 \pm 0.00^{a}$ & $38.00 \pm 0.00^{a}$ & $38.00 \pm 0.00^{c}$ & $38.00 \pm 0.00^{a}$ \\
\hline
\end{tabular}

Table 8: Zone of Inhibition ( $\mathrm{mm}$ ) of partially purified ethylacetate fraction of methanol pulp extract against $E$. coli. 


\begin{tabular}{|c|c|c|c|c|}
\hline Conc/Std $(\boldsymbol{\mu g})$ & \multicolumn{4}{|c|}{ Zone of Inhibition (mm) } \\
\hline & A & B & C & D \\
\hline 50 & - & - & - & $19.5 \pm 0.70^{\mathrm{c}}$ \\
\hline 25 & - & - & - & $14.5 \pm 0.70^{\mathrm{b}}$ \\
\hline 12.5 & - & - & - & $10.0 \pm 0.00^{\mathrm{a}}$ \\
\hline 6.5 & - & - & - & - \\
\hline Cipro 10 & $39.5 \pm 0.70^{\mathrm{a}}$ & $39.5 \pm 0.70^{\mathrm{a}}$ & $39.5 \pm 0.70^{\mathrm{a}}$ & $39.5 \pm 0.70^{\mathrm{d}}$ \\
\hline
\end{tabular}

Values are in mean \pm SD of double determinations. Values with different superscripts across the column are significantly different ( $p<0.05)$. Cipro: Ciprofloxacin, $-:$ No zone of Inhibition.

Table 9: Zone of Inhibition $(\mathrm{mm})$ of partially purified ethyl-acetate fraction of methanol pulp extract against Salmonella typhi

\begin{tabular}{|c|c|c|c|c|}
\hline \multirow[t]{2}{*}{ Conc/Std $(\mu g)$} & \multicolumn{4}{|c|}{ Zone of Inhibition (mm) } \\
\hline & $A$ & B & $\mathrm{C}$ & $\mathrm{D}$ \\
\hline 50 & - & $12.00 \pm 0.00^{\mathrm{b}}$ & $28.00 \pm 1.41^{\mathrm{d}}$ & - \\
\hline 25 & - & $10.00 \pm 0.00^{\mathrm{a}}$ & $19.00 \pm 1.41^{c}$ & - \\
\hline 12.5 & - & - & $14.00 \pm 1.41^{\mathrm{b}}$ & - \\
\hline 6.5 & - & - & $10.00 \pm 0.00^{\mathrm{a}}$ & - \\
\hline Cipro 10 & $41.00 \pm 1.41^{\mathrm{a}}$ & $41.00 \pm 1.41^{c}$ & $41.00 \pm 1.41^{c}$ & $41.00 \pm 1.41^{\mathrm{a}}$ \\
\hline
\end{tabular}

Values are in mean \pm SD of double determinations. Values with different superscripts across the column are significantly different ( $p<0.05)$. Cipro: Ciprofloxacin, -: No zone of Inhibition.

Table 10: Zone of Inhibition ( $\mathrm{mm}$ ) of Partially Purified Ethyl-acetate Fraction of methanol pulp Extract against Staphylococcus aureus.

\begin{tabular}{|c|c|c|c|c|}
\hline \multirow[t]{2}{*}{ Conc/Std $(\mu \mathrm{g})$} & \multicolumn{4}{|c|}{ Zone of Inhibition (mm) } \\
\hline & A & B & $\mathrm{C}$ & $\mathrm{D}$ \\
\hline 50 & - & $11.00 \pm 1.00^{a}$ & $29.0 \pm 0.00^{\mathrm{a}}$ & - \\
\hline 25 & - & $11.00 \pm 1.00^{a}$ & $19.00 \pm 1.41^{b}$ & - \\
\hline 12.5 & - & - & $18.00 \pm 0.00^{\mathrm{b}}$ & - \\
\hline 6.5 & - & - & $13.00 \pm 0.00^{a}$ & - \\
\hline Cipro 10 & $31.50 \pm 0.70^{\mathrm{a}}$ & $31.50 \pm 0.70^{b}$ & $31.50 \pm 0.70^{d}$ & $31.50 \pm 0.70^{\mathrm{a}}$ \\
\hline
\end{tabular}

Values are in mean \pm SD of double determinations. Values with different superscripts across the column are significantly different ( $<<0.05)$. Cipro: Ciprofloxacin, -: No zone of Inhibition.

Table 11: Zone of Inhibition $(\mathrm{mm})$ of partially purified ethyl-acetate fraction of methanol pulp extract against Bacillus subtilis.

a continuous search for new effective and affordable antimicrobial drugs. Column chromatographic analysis of the ethyl-acetate fraction of the pulp using silica gel chromatography resulted in one hundred fractions which were later poled together to four fractions (A-D) (as shown in Table 1) base on their TLC profile. Anti-microbial activities of the fractions showed that fraction A was not active against the entire organism tested. Fraction B showed potent activity against Staphyloccus aureus and Bacillus subsilis at 25 and $50 \mathrm{mg} / \mathrm{ml}$. Fraction $\mathrm{C}$ at all the tested doses demonstrated maximum anti-bacterial activity ranging from 10.00-29.50 against the entire tested organism except for Salmonella typhia. It is possible that component(s) essential for Salmonella typhia antibacterial activity is/are lost in fraction C. Fraction D was active at concentration of $12.5-50 \mathrm{mg} / \mathrm{ml}$ against salmonella typhi only. The fractionation of the ethylacetate pulp extract improved the anti-bacterial activity in Fraction $\mathrm{C}$ against all the tested organisms. This result showed that the fractionation process concentrated the active principle in fraction C. Similar results were reported by Mansouri, et al. [27], when evaluating the antibacterial activity of the crude extracts and fractionated constituents of Myrtuscommunis. The results of this study do not only show the scientific basis for some of the therapeutic uses of the plant in traditional medicine, but also confirms the impact of ethno botanical approach when investigating plants for their antimicrobial properties [26].

\section{Conclusion}

Base on this study, it may be concluded that the pulp of $Z$. mauritiana possess a wide range of phytochemicals which demonstrated antimicrobial activities, in both crude and fractionated extracts, which could be attributed to the presence of secondary metabolites such as tannins, terpenoids, and flavonoids which are known in related literatures for their antimicrobial functions, $[19,20,24,25]$ as well as increase in concentrations of the extracts. The results of this study show the scientific basis for some of the therapeutic uses of the plant in traditional medicine and also confirm the impact of ethnobotanical approach when investigating plants for their antimicrobial properties [27].

\section{References}

1. Cos P, Vlietinck AJ, Berghe DV, Maes L (2006) Anti-infective potential of natural products: how to develop a stronger in vitro 'proof-of-concept'. Journal of Ethnopharmacology 106: 290-302.

2. Sasidharan S, Chen Y, Saravanan D, Sundram KM, Latha LY (2011) Extraction, isolation and characterization of bioactive compounds from plants' extracts. African Journal of Traditional, Complementary and Alternative Medicines 8: 1-10.

3. Saxena M, Saxena J, Nema R, Singh D, Gupta A (2013) Phytochemistry of Medicinal Plants. Journal of Pharmacognosy and Phytochemistry.

4. Louis H, Linus MN, Israt A, Innocent J, Amos PI, et al. (2018) Antimicrobial Activity of Stem, Leave and Root Plant Extract of Sclerocarya birrea and Sterculia setigera against Some Selected Microorganisms. World Scientific News an International Scientific Journal WSN 92: 309-326.

5. Najafi S (2013) Phytochemical screening and antibacterial activity of leaf Extract of Ziziphus mauritiana Lam. International Research Journal of Applied and Basic Sciences 4: 3274-3276.

6. Samy RP, Ignacimuthu S (2000) Antibacterial activity of some folklore medicinal plants used by tribals in Western Ghats in India. Journal of Ethnopharmacology 69: 63-71.

7. Palombo EA, Semple SJ (2001) Anti-bacterial activity of traditional medicina plants. Journal of Ethnopharmacology 77: 151-157. 
Citation: Mbahi MA, Mbahi AM, Umar IA, Ameh DA, Joseph I, et al. (2018) Phytochemical Screening and Antimicrobial Activity of the Pulp Extract and Fractions of Ziziphus mauritiana. Biochem Anal Biochem 7: 352. doi: 10.4172/2161-1009.1000352

Page 6 of 6

8. Kumaraswamy Y, Cox PJ, Jaspars L, Nahar S, Sarker SD (2002) Screening seeds of scotish plants for antibacterial activity. Journal Ethnopharmacology 83: 73-77.

9. Morton J (1987) Indian Jujube. In: Morton JF (ed.) Pulp of Warm Climates. Miami, Florida, 272-275, Last updated: 23/4/2004.

10. Msonthi JD, Magombo D (1983) Medicinal herbs in Malawi and their uses. Hamdard 26: 94-100.

11. Lilja T (2013) Isolating microorganisms from marine and marine-associated samples - A targeted search for novel natural antibiotics.

12. Jumare FM, Suleiman AB, Afegbua SL, Anchau ZG (2015) Synergistic Antibacterial Activity among Crude Extracts of Allium sativum and Citrus Limon Using Checkerboard Microdilution Method. International Journal of Science and Research 4: 6.

13. Cheesbrough M (2002) District laboratory practice in tropical countries. Cambridge University Press, London 2: 137-140.

14. Trease GE, Evans WC (1983) Pharmacognosy. (12thedn), Bailere Tindall, Macmillan, London, pp: 45-50.

15. Sofowora A (1993) Medicinal plants and traditional medicine in Africa. John Wiley and Sons, New York, pp: 191-300.

16. Allen SE, Grimshaw HM, Parkinson JA, Quarmby C (1974) Chemical Analysis of Ecological Materials, Oxford, Blackwell Scientific.

17. Irobi ON, Moo-Young M, Anderson WA, Daramola SO (1994) Antimicrobial activity of bark extracts of Bridelia ferruginea (Euphorbiaceae). Journal of Ethnopharmacology 43: 185-190.

18. Michel A (2002) Tree, Shrub and Liana of West African Zone. Margraf Publishers, GMBH, Paris, p: 440.
19. Dahiru D, Sini JM, John-Africa L (2006) Antidiarrhoeal activity of Ziziphusmauritiana root extract in rodents. African Journal of Biotechnology.

20. Dahiru D, Obidoa O (2008) Evaluation of the antioxidant effects of Ziziphusmauritiana lam. leaf extracts against chronic ethanol-induced hepatotoxicity in rat liver. African Journal of Traditional, Complementary and Alternative Medicines 5: 39-45.

21. Daisy P, Salu Mathew SS, Rayan NA (2008) A novel terpenoid from Elephantopusscaber-antibacterial activity on Staphylococcus aureus: a substantiate computational approach. International Journal of Biomedical Science 4: 196.

22. Prescott LM, Harley JP, Klein D (2002) Microbiology (International Edition), fifth edition. MC Graw Hill Book Company 809: 818-819.

23. Achi OK (2010) Composition and antibacterial activities of Tetrapleuratetraptera Taub. Pod extracts. Research Journal of Microbiology 5: 1138-1144.

24. Yusha'u M, Hassan A, Kawo AH (2008) Public health implications of the bacterial load of stethoscopes of some clinicians in Kano, Nigeria. Biology and Environmental Science. Tropical Journal 5: 196-199.

25. Tringali C (2005) Identification of bioactive metabolites from the bark of Pericopsis (Aformosia) laxiflora. Phytochemical Analysis 6: 289-291.

26. Mansouri S, Foroumadi A, Ghaneie T, Najar AG (2001) Antibacterial activity of the crude extracts and fractionated constituents of Myrtuscommunis Pharmaceutical Biology 39: 399-401.

27. Adesanya SA (2005) From Nature to Drugs: Theories and Realities. Obafemi Awolowo University Press, Osun State, Nigeria. 